\title{
Методичний підхід до визначення можливостей системи відновлення озброєння та військової техніки з технічної розвідки
}

\author{
Андрій Звонко * 1 А; Ігор Овчаренко ${ }^{2}$; ; Олександр Ярошенко ${ }^{3 \text { в; }}$ \\ Павлов Денис ${ }^{4}$ в \\ А Національна академія сухопутних військ імені гетьмана Петра Сагайдачного, м. Львів, Україна \\ в Національний університет оборони України імені Івана Черняховського, м. Київ, Україна
}

Received: October 7, 2021 | Revised: October 19, 2021 | Accepted: October 30, 2021

DOI: $10.33445 /$ sds.2021.11.5.14

\begin{abstract}
Анотація
Аналіз виконання бойових завдань підрозділами та військовими частинами ЗС України з зоні проведення антитерористичної операції (АТО) на території Донецької та Луганської областей вказує на зміну сучасних форм та способів застосування військ (сил), що призводить до необхідності удосконалення існуючих та пошуку нових способів виконання завдань 3 логістичного забезпечення, зокрема з відновлення пошкоджених зразків озброєння та військової техніки (ОВТ). Комплексна методика функціонування системи відновлення ОВТ включає два основних розрахункових блоки, а саме: методику визначення можливого обсягу втрат ОВТ та сил і засобів ремонтно-відновлюваних органів (РВО); методику визначення можливостей РВО щодо відновлення ОВТ, яка включає часткові методики визначення можливостей з технічної розвідки, евакуації та ремонту ОВТ.
\end{abstract}

Ключові слова: відновлення озброєння та військової техніки, технічна розвідка, ремонтновідновлювальні органи.

\section{Постановка проблеми}

Наявність працездатних зразків ОВТ в військових частинах (підрозділах) є одним із показників боєздатності відповідного підрозділу. Одним із основних способів підтримання даного показника $€$ своєчасне відновлення ОВТ в ході ведення бойових дій. Першим етапом комплексу робіт 3 відновлення ОВТ $€$ технічна розвідка (ТхР), без якої подальше виконання завдань щодо відновлення ОВТ $€$ неможливим. На даний час організація TхР ремонтновідновлювальними підрозділами військових частин не в повній мірі відповідає вимогам ведення бойових дій та розвитку науковотехнічної бази країни. А від успішної розвідки пошкодженого зразка ОВТ буде залежати подальше виконання усіх інших заходів, які спрямовані на вчасне забезпечення підрозділу відновленими в ході бою зразками ОВТ [1].

Застосування традиційних методів керівництва, що ґрунтуються на інтуїції та досвіді керівника в ході визначення необхідного складу підрозділів для виконання поставленого завдання, стає недостатнім для прийняття обґрунтованого рішення, в таких випадках доцільно використати науковий підхід для вирішення такого роду завдань.

\footnotetext{
1 * Corresponding author: кандидат технічних наук, доцент, доцент кафедри, e-mail: zvonko2008@ukr.net, ORCID: 0000-0002-7410-799X

2 кандидат технічних наук, доцент, професор кафедри, e-mail: i-v-o@ukr.net, ORCID: 0000-0001-9066-0800

${ }^{3}$ старший викладач кафедри, e-mail: kss2014@ukr.net, ORCID: 0000-0001-9497-2262

${ }^{4}$ ад'юнкт кафедри, e-mail: pavlovdenis81@ukr.net, ORCID: 0000-0003-3348-7655
} 
Аналіз останніх досліджень та публікацій

Дослідженню питань підвищення ефективності систем такого типу приділяється багато уваги. Так в роботі [2] досліджується питання найбільш складних етапів відновлення - евакуації та ремонту. Питанням технічної розвідки (ТхР) приділялась незначна увага, а у більшості випадків імовірність виявлення пошкоджених зразків ОВТ приймалась рівною 1. В публікації [3] для підвищення ефективності функціонування системи відновлення озброєння та військової техніки запропонована методика проектування ремонтно-відновлювальних органів. В роботі вказується про потребу у переоснащенні ремонтно-відновлювальних підрозділів відповідними технічними засобами з метою підвищення ефективності ведення ТхР, але не конкретизовано чим саме проводити удосконалення. В роботі [4] пропонується методичний підхід до оцінки економічної ефективність відновлення зразків озброєння та військової техніки. Цей підхід включає два способи: фінансово-економічні витрати на ремонт озброєння та військової техніки в стаціонарних умовних та в рухомих ремонтно-відновлювальних військових частинах. Але в роботі не зазначений порядок оцінювання витрат на переоснащення засобів для ведення ТхР в цілому. Автор публікації [5] розглядає необхідність використання безпілотних літальних апаратів 3 метою удосконалення заходів ТхР під час виконання спеціальних завдань підрозділами Національної гвардії України, але тактикотехнічні вимоги і характеристики цих засобів в статті не визначає. В роботі [6] розглянуто способи оцінювання ефективності вирішення завдань силами повітряної розвідки а також раціональне шикування літаків-розвідників в повітрі для виявлення повітряних цілей на встановлених рубежах. При оцінюванні якості вирішення завдань повітряної розвідки використовувалися в основному методи теорії імовірностей в якості основи визначення потенціалу підсистеми складних організаційно-цілеспрямованих систем. В роботі [7] автором досліджуються існуючі способи ведення космічної та повітряної розвідки замаскованих об'єктів. Виявлені недоліки космічної розвідки у вирішенні завдань даного виду. Визначені переваги повітряної розвідки у вирішенні завдань розвідки замаскованих об'єктів та доцільність застосування для цього безпілотних літальних апаратів внаслідок ряду переваг над пілотованими розвідувальними засобами але вказані переваги не підтверджені ні математичним моделюванням, ні імітаційним моделюванням, а у роботі [8] запропоновано підхід до оцінювання можливостей виконання заходів 3 ремонту ОВТ ремонтновідновлювальними органами (РВО) під час виконання завдань за призначенням про те даний підхід не враховує як на ефективність виконання завдань з ремонту буде впливати ефективність виконання завдань 3 ТхР. Роботи [9, 10] присвячені побудові математичних моделей які описують ефективність функціонування системи відновлення, але дані роботи не враховують підвищення ефективності системи технічної розвідки за рахунок оснащення ГТР технологічним обладнанням. В роботі [11], розглядаються питання, щодо раціональної кількості груп технічної розвідки (ПР) але не розглядаються питання як саме зменшити час пошуку пошкодженого зразка ОВТ і тим самим підвищити ефективність ТхР. В роботі [12] запропонована часткова методика оцінки можливостей виконання завдань 3 TxP в загальній системі логістичного забезпечення, але дана методика залежить від імовірних втрат ОВТ і визначає можливості лише стаціонарних органів технічної розвідки, а можливості рухомих органів технічної розвідки (ОТхР) не враховує. 


\section{Постановка завдання}

В даний час застосовується так званий об'єктовий спосіб організації ТхР, при якому ОТхР розподіляються по найважливіших об'єктах (районах, рубежах) в смузі операції і мають завдання добувати достовірні дані стосовно питань, які покладаються на ОТхР. Однак, такий підхід не дозволяє повністю охопити всі необхідні об'єкти і вимагає періодичного переорієнтування вже задіяних сил і засобів на вирішення задач, які виникають раптово. Як наслідок, органам управління необхідно витрачати значний час на вирішення оптимізаційних завдань 3 Виклад основного матеріалу

Одним із шляхів вирішення цієї проблеми $\epsilon$ пошук і впровадження в теорію і практику процесу відновлення ОВТ нових, перспективних способів ведення ТхР, заснованих на застосуванні сучасних, більш ефективних засобів добування, обробки та оперативного доведення споживачам даних щодо місць виходу ОВТ з ладу в смузі операції (бойових дій). Так, до значного підвищення можливостей підрозділів технічної розвідки може привести використання сучасних технічних засобів пошуку та визначення місць розташування пошкоджених зразків ОВТ.

Одним із шляхів підвищення ефективності виконання завдань з ТхР $€$ зменшення часу пошуку пошкоджених зразків ОВТ шляхом підвищення мобільності ОТхР за рахунок забезпечення даних органів засобами рухомості. Для ведення ТхР найбільш прийнятними $€$ створення та впровадження машини технічної розвідки $[13,14]$. Оснащення PBO даним зразком надасть можливість перейти від об'єктового до більш ефективного - зонального способу ведення технічної розвідки.

Суть цього способу полягає у визначенні підрозділам ТхР на весь період операції зон відповідальності (в смузі). В межах зони (напрямку) будь-яка точка (об'єкт) місцевості буде досяжна для ведення ТхР завдяки застосуванню машини технічної розвідки. Це переорієнтування ОТхР на вирішення нових завдань, а самим органам - здійснювати складні маневри на значні відстані. Все це призводить до збільшення термінів добування інформації щодо місць знаходження та стану пошкоджених зразків OВT, що в свою чергу знижує рівень оперативності вирішення завдань з евакуації та завантаження ремонтних підрозділів ремонтним фондом.

Мета статті полягає у формуванні основних підходів щодо розроблення методики визначення можливостей рухомих ОТхР.

дозволить ОТхР здійснювати безперервний моніторинг місцевості з повним охопленням смуги операції, здійснюючи, при необхідності, маневр силами та засобами.

Однак цей спосіб, поряд з незаперечними перевагами, має такі ж недоліки, що і об'єктовий. Досвід бойових дій військ на Сході України показує, що в сучасних умовах більш ефективним $\epsilon$ системний спосіб ведення технічної розвідки. У сучасних умовах переходу на автоматизовану систему управління процесом відновлення ОВТ, де одним 3 основних принципів управління $\epsilon$ управління ситуацією, в якій розвиваються бойові дії, виникають питання отримання більшого об'єму і якості інформації. Суть системного методу ведення ТхР полягає в комплексній оцінці району бойових дій до початку бою і прогнозуванні місць виходу ОВТ з ладу в ході виконання бойових завдань по етапам 3 постійним нарощуванням даних від етапу до етапу. Для ефективного моніторингу району бойових дій рухомий ОТхР доцільно оснастити розвідувальною машиною на гусеничній [15] або на колісній базі [16] із відповідним оснащенням.

Для визначення ефективності системного способу ведення технічної розвідки необхідно провести математичне моделювання, яке використовувалося при оцінці зонального способу. При цьому, використано комплекс 
критеріїв, в якому в якості основного прийнята достовірність розвідувальних відомостей, що добуваються, а в якості додаткових періодичність оновлення розвідувальної інформації, що характеризує оперативність ТхР, і інтенсивність потоку виявлень, що характеризує продуктивність сил ТхР [17].

Чисельні значення основного критерію ефективності (достовірність розвідувальних відомостей) в моделі визначено як ефект сумарної дії органів технічної розвідки:

$$
Д_{\mathrm{i}}=1-\Pi_{\mathrm{i}-1}^{\mathrm{x}}\left(1-D_{i j}\right)^{\mathrm{x}_{\mathrm{i}}}
$$

де: $j$ - тип пошкодженого зразка ОВТ, який буде виявлений ОТхР;

$i$ - тип органу технічної розвідки;

$D_{\mathrm{i} j}$ - математичне сподівання значень достовірності як результат сумарного впливу органів технічної розвідки на виявлення пошкодженого зразка ОВТ $j$-го типу.

Математичне сподівання значень достовірності розраховується за формулою:

$$
D_{i j}=1-\left(1-P_{1}\right)-\left(1-P_{2}\right) \ldots\left(1-P_{i}\right)(2)
$$

де: $P_{i}$ - ймовірність виявлення пошкодженого зразка ОВТ $j$-го типу одним розвідувальним органом типу $i$, яка в свою чергу, визначається наступним виразом:

$$
P_{i}=P_{\text {потр }}^{t} P_{\text {вид }}^{t} P_{\text {роз }}^{t} P_{\text {прот }}^{t}
$$

де: $P_{\text {потр }}^{t}$ - імовірність потрапляння за час $t$ пошкодженого зразка ОВТ $j$-го типу в зону пошуку;

$P_{\text {вид }}^{t}-$ імовірність наявності прямої видимості до $j$-го пошкодженого зразка ОВТ;

$P_{\text {прот }}^{t}-$ імовірність розпізнавання за час $t, j$ го пошкодженого зразка ОВT, що потрапив в зону пошуку, конкретним органом технічної розвідки;

$P_{\text {прот }}^{t}$ - імовірність того, що противник не зможе завадити розвідці $j$-го пошкодженого зразка ОВТ.

Чисельні значення періоду поновлення розвідувальної інформації органами технічної розвідки визначені за такою залежністю:

$$
T_{n}=\frac{T_{p}}{n\left[1-P_{v}\left(\tau_{\text {д }}\right)\right]}
$$

де: $\mathrm{T}_{\mathrm{p}}$ - сумарний час роботи ОТхР за операцію;

$n$ - загальне число пошкоджених зразків OBT;

$P_{v}\left(\tau_{\text {д }}\right) \quad-\quad$ імовірність виявлення пошкодженого зразка ОВТ за допустимий час $\tau_{\text {Д. }}$

Чисельні значення інтенсивності потоку виявлень пошкоджених зразків ОВТ визначені за наступною формулою:

$$
\gamma=\frac{2 D_{p} V_{p} k P_{k}}{S}
$$

де: $D_{p}$ - дальність дії засобів спостереження органу технічної розвідки (км);

$V_{p}$ - швидкість пересування органу технічної розвідки (км/год);

$k$-кількість об'єктів технічної розвідки в зоні відповідальності;

$P_{k}$ - імовірність того, що з пошкодженим зразком ОВТ, який потрапив в зону виявлення буде встановлений контакт;

$S$ - площа району пошуку або зони відповідальності (км²).

Проведене таким чином математичне моделювання дозволяє за допомогою кількісних показників обґрунтувати переваги системного способу ведення технічної розвідки в порівнянні з об'єктовим.

По-перше, досягаються більш високі значення достовірності добування розвідувальної інформації органом технічної розвідки (0,5-0,7 проти 0,2-0,4).

По-друге, підвищується продуктивність ОТхР, оскільки інтенсивність потоку виявлень зростає до 50 виявлень на годину.

По-третє, зменшується період оновлення розвідувальної інформації ( $\mathrm{T} \leq 1$ година).

Разом з тим впровадження системного способу ведення технічної розвідки пов'язане зі значними витратами фінансових i матеріальних ресурсів. Обумовлено це насамперед необхідністю оснащення підрозділів технічної розвідки машинами технічної розвідки, які укомплектовані технічними засобами автоматизації збору, обробки, зберігання та передачі розвідувальної інформації [18]. 
У зв'язку з цим постає необхідність вибору оптимального варіанта застосування сил i засобів технічної розвідки в операції, що забезпечує досягнення ії цілей при раціональному витрачанні матеріальних, трудових і фінансових ресурсів. Його вирішення можливе шляхом кількісної оцінки інтегрального критерію ефективності, що характеризує вартість одиниці отриманого ефекту:

$$
W=\frac{W_{\mathrm{B}}}{W_{\mathrm{e}}}
$$

де: $W_{\text {в }}$ - критерій вартості, що має економічний зміст, за який приймаються витрати на проведення заходів технічної розвідки об'єктовим і системним способами;

$W_{\text {е }}$ - критерій ефективності, що характеризує результат здійснення запропонованих заходів, за який прийнята достовірність видобування розвідувальних даних як ефект (результат) діяльності ОТхР.

Розрахунки показують, що навіть при дворазовому зростанні фінансових i матеріальних витрат, вартість умовної одиниці достовірності отриманої інформації при системному способі ведення технічної розвідки на 4-10\% нижче, ніж при об'єктовому способі.

\section{Висновки}

Таким чином, впровадження системного способу ведення технічної розвідки сприяє підвищенню автономності застосування ОТхР, повному охопленню ними всієї смуги (району) на всю глибину проведення операції, скороченню часового циклу управління ОТхР i, що особливо важливо,
Оскільки метою технічної розвідки $\epsilon$ своєчасне добування, збір, обробка і доведення споживачам достовірних даних про місце виходу ОВТ з ладу в смузі ведення операції в інтересах прийняття ними рішень, слід встановити, як пропонований спосіб сприятиме досягненню зазначеної мети.

Ефективність прийнятого рішення в умовах невизначеності, яка характерна для управління відновленням ОВТ в ході сучасних військових конфліктів, істотно залежить від достовірності наявної інформації. 3 цієї точки зору в теорії управління вивчаються три групи рішень [19].

1. Прийняті в умовах повної визначеності, коли потрібна інформація 3 достовірністю не

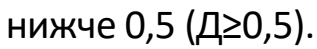

2. Прийняті в умовах неповної визначеності $(0,3 \leq Д \leq 0,5)$.

3. Прийняті в умовах повної невизначеності (Д $\leq 0,3)$.

Як показують результати математичного моделювання, пропонований системний спосіб ведення технічної розвідки дозволяє добувати відомості з достовірністю від 0,5 до 0,7, що забезпечує заступнику командира 3 озброєння та іншим споживачам інформації (начальникам служб) можливість приймати рішення в умовах, близьких до умов повної визначеності.

досягненню високого ступеня оперативності забезпечення інформацією споживачів (заступника командира 3 озброєння, начальників служб) про місця виходу ОВТ 3 ладу 3 достовірністю, що дозволяє їм приймати рішення в умовах, близьких до повної визначеності.

\section{Список використаних джерел}

1. Sampir, O. (2021). Improvement of the method of determining opportunities for technical exploration of damaged samples of weapons during combat. Journal of Scientific Papers "Social Development and Security", 11(2), 141151. DOI: 10.33445/sds.2021.11.2.14

2. Стрельбіцький М. А. Математична модель функціонування системи відновлення озброєння та військової техніки / Стрельбіцький М.А., Дачковський В.О. // "Сучасні інформаційні технології у сфері безпеки та оборони", НУОУ. - 2020. - № 2(38) C. 87 - 94. DOI: 10.33099/23117249/2020-38-2-87-94

3. Ярошенко В.О., Овчаренко О.В., Дачковський І.В., Сампір О.М. Методика проектування 
ремонтно-відновлювальних органів.

Збірник наукових праць військової академії (м. Одеса), 2020. № 13(1), ч. І, с. 210-222. DOI: $10.37129 / 2313-7509.2020 .13 .1 .210-222$

4. Horbachova Y. Sampir, O. Dachkovskyi, V. (2020) Methodical approach to evaluation of economic efficiency of repairing the weapons and military equipment. Journal of Scientific Papers VUZF review, Vol. 5, No 1, p. 22-30. DOI: 10.38188/2534-9228.20.1.03

5. Гончар, Р.О. Власов, К.В. Забула, О.Є. Спосіб ведення технічної розвідки підрозділами Національної гвардії України 3 використанням безпілотних літальних апаратів. Збірник наукових праць Військового інституту внутрішніх військ МВС України. 2019. № 3 (70) с.210-222. ISSN 2078-7480

6. Оцінювання ефективності повітряної розвідки при плануванні бойового застосування її засобів / О.І. Волков, Г.В. Пєвцов, В.А. Клименко, Ю.Б. Ситник // Наука і техніка Повітряних Сил Збройних Сил України. - 2010. - № 2(4). - С. 36-40.

7. Досвід ведення повітряної розвідки замаскованих об'єктів / С.С. Невгад, А.П. Корнієнко// Збірник наукових праць Харківського університету Повітряних Сил. 2009. - № 1(19). - С. 21-25. ISSN 2073-7378

8. Цуркан, М., \& Дачковський, В. (2021). Методика оцінювання можливості виконання заходів з ремонту озброєння та військової техніки. Збірник наукових праць

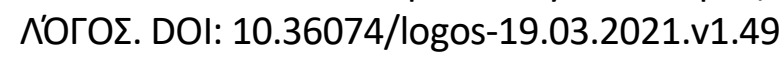

9. Коцюруба В. І. Методика оцінювання ефективності функціонування системи відновлення озброєння та військової техніки / В.І. Коцюруба, В.О. Дачковський // науковий журнал "Сучасні інформаційні технології у сфері безпеки та оборони", HYOY. - 2020. - № 1(37) C. 5 - 14. DOI: 10.33099/2311-7249/2020-37-1-5-14

10. Гудима, В., Дачковський, В., \& Сампір, О. (2021). Методичний підхід до прогнозування потоку ремонтного фонду зразків озброєння та військової техніки.

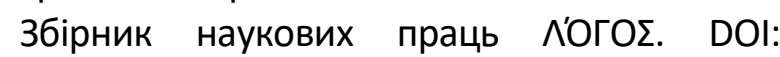

10.36074/logos-26.02.2021.v1.40

11. Dachkovskyi, V. (2019). Methodology of justification of tactical and technical requirements for movable means of repairing arms and military equipment. Journal of Scientific Papers "Social Development and Security», 9(6), 86-101. DOI: 10.33445/sds.2019.9.6.7

12. Dachkovskyi, V. (2021). Methods of evaluation of efficiency of logistic operations. Journal of Scientific Papers "Social Development and Security", 11(1), 179-196. DOI: 10.33445/sds.2021.11.1.17

13. Пат. 102083 Україна, МПК (2013) F41H 7/00. Машина технічної розвідки (МТР-1) / Дачковський В.О.; - заявник і володар патенту Дачковський В.О. - № u201504517; заяв. 8.05.2015; опубл. 12.10.2015; Бюл. № 19. URL: https://uapatents.com/8-102083mashina-tekhnichno-rozvidki-mtr-1.html

14. Пат. 105092 Україна, МПК (2013) F41H 7/00. Машина технічної розвідки (МТР-2) / Дачковський В.О., Коцюруба В.І., Даценко І.П.; - заявник і володар патенту НУОУ - № u201506514; заяв. 02.07.2015; опубл. 10.03.2016; Бюл. № 5 . URL: https://uapatents.com/6-105092-mashinatekhnichno-rozvidki-mtr-2.html

15. Пат. 122446 Україна, МПК (2009) F41 H 7/00. Базова гусенична платформа модульного типу/ Дачковський В.О., Овчаренко І.В., Ярошенко О.В., Сампір О.М., Куровська Т.Ю. - заявник і володар патенту Дачковський В.О. - № а201812481; заяв. 17.12.2018; опубл. 10.11.2020, Бюл. №21/2020

16. Пат. 135430 Україна, МПК (2017) B60 S 5/00. Машина технічної допомоги (МТД-Б) / Дачковський В.О., Сампір О.М., Ярошенко О.В., Овчаренко І.В., - заявник і володар патенту Національний університет оборони України ім. Івана Черняховського - № u201901427; заяв. 12.02.2019; опубл. 25.06.2019; Бюл. № 12.

17. Левченко М.А., Дачковський В.О. Математична модель виконання завдань 3 технічної розвідки. Міжнародний науковий журнал «Грааль науки» № 6 (Червень, 2021): 
за матеріалами I Міжнародної науковопрактичної конференції «Modern science: concepts, theories and methods of basic and applied research», що проводилася 25 червня 2021 року «International Centre Corporative Management» (Відень, Австрія). p. 87-90. DOI: 10.36074/grail-ofscience.25.06.2021.015

18. Левченко М.А., Дачковський В.О. Оцінювання ефективності застосування рухомих засобів ремонту озброєння та військової техніки Scientific Collection "InterConf", (66): with the Proceedings of the 9th International Scientific and Practical
Conference "Challenges in Science of Nowadays" (July 16-18, 2021). Washington, USA: EnDeavours Publisher, 2021.p. 510-513. DOI: 10.36074/logos-19.03.2021.v1.49

19. Іщенко М. І., Адамовська В. С., Краснова Г. М. Особливості оцінки ефективності прийняття управлінських рішень органами місцевого самоврядування. Державне управління: удосконалення та розвиток. 2019. № $6 . \quad$ - 6 URL: http://www.dy.nayka.com.ua/?op=1\&z=1447 (дата звернення: 04.11.2021). DOI: 10.32702/2307-2156-2019.6.2

\title{
Методический подход к определению возможностей системы восстановления вооружения и военной техники из технической разведки
}

\author{
Андрей Звонко * 1 А; Игорь Овчаренко 2 в; Александр Ярошенко 3 в; \\ Денис Павлов ${ }^{4 \text { в }}$ \\ * Corresponding author: ${ }^{1}$ кандидат технических наук, доцент, доцент кафедры, e-mail: (hidden) ORCID:0000-0002-7410-799X \\ ${ }^{2}$ кандидат технических наук, професор кафедры, e-mail: i-v-o@ukr.net, ORCID: 0000-0001-9066-0800 \\ ${ }^{3}$ старший преподаватель кафедры e-mail: kss2014@ukr.net, ORCID: 0000-0001-9497-2262 \\ 4 адъюнкт кафедры e-mail: pavlovdenis81@ukr.net, ORCID: 0000-0001-9497-2262 \\ А Национальная академия сухопутных войск имени гетмана Петра Сагайдачного, г. Львов, Украина \\ в Национальный университет обороны Украины имени Ивана Черняховского, Киев, Украина
}

\begin{abstract}
Аннотация
Анализ выполнения боевых задач подразделениями и воинскими частями ВС Украины в зоне проведения антитеррористической операции (АТО) на территории Донецкой и Луганской областей указывает на изменение современных форм и способов применения войск (сил), что приводит к необходимости усовершенствования существующих и поиска новых способов выполнения задач по логистического обеспечения, в частности восстановления поврежденных образцов вооружения и военной техники (ВВТ). Комплексная методика функционирования системы восстановления ВВТ включает два основных расчетных блока, а именно: методику определения возможного объема потерь ВВТ и сил и средств ремонтно-восстанавливаемых органов (РВО); методику определения возможностей РВО по восстановлению ВВТ, которая включает частные методики определения возможностей по технической разведке, эвакуации и ремонту ВВТ.
\end{abstract}

Ключевые слова: восстановление вооружения и военной техники, техническая разведка, ремонтно-восстановительные органы.

\section{Methodical approach to determining the possibilities of the weapon restoration system and military equipment for technical intelligence}




\title{
Andrey Zvonko * 1 A; Igor Ovcharenko ${ }^{2}$ B Alexander Yaroshenko $^{3 \text { B }}$; Denis Pavlov 4 B
}

* Corresponding author: ${ }^{1}$ Candidate of Technical Sciences, assistant Professor of the Department, e-mail: zvonko2008@ukr.net, ORCID: 0000-0002-7410-799X

${ }^{2}$ Candidate of Technical Sciences, Professor of the Department, e-mail: i-v-o@ukr.net, ORCID: 0000-0001-9066-0800

${ }_{3}^{3}$ Senior lecturer, e-mail: kss2014@ukr.net, ORCID: 0000-0001-9497-2262

${ }^{4}$ PhD student, e-mail: pavlovdenis81@ukr.net, ORCID:0000-0003-3348-7655

A Hetman Petro Sahaidachnyi National Army Academy, Lviv, Ukraine

${ }^{B}$ National Defence University of Ukraine named after Ivan Cherniachovskyi, Kyiv, Ukraine

\begin{abstract}
An analysis of the performance of combat missions by subunits and military units of the Armed Forces of Ukraine in the area of the anti-terrorist operation on the territory of Donetsk and Lugansk regions indicates a change in modern forms and methods of using troops (forces), which leads to the need to improve existing and search for new ways of performing tasks on logistics support, in particular the restoration of damaged weapons and military equipment. The comprehensive methodology for the functioning of the AME recovery system includes two main calculation blocks, namely: methodology for determining the possible volume of losses of weapons and military equipment and forces and means of repair and remanufactured organs (RVO); a methodology for determining the capabilities of the RPO for the restoration of weapons and military equipment, which includes specific methods for determining the capabilities for technical reconnaissance, evacuation and repair of weapons and military equipment.
\end{abstract}

Keywords: restoration of weapons and military equipment, technical intelligence, repair and restoration bodies.

\section{References}

1. Sampir, O. (2021). Improvement of the method of determining opportunities for technical exploration of damaged samples of weapons during combat.Journal of Scientific Papers "Social Development and Security", 11(2), 141151. DOI: $10.33445 / s d s .2021 .11 .2 .14$

2. Strelbitsky, M. A., Dachkovsky, V. O. (2020). Mathematical model of functioning of the system of restoration of armaments and military equipment. Modern information technologies in the field of security and defense, № 2 (38) P. 87 - 94. DOI: 10.33099/23117249/2020-38-2-87-94

3. Yaroshenko, O.V., Ovcharenko, I.V., Dachkovsky, V.O., Sampir, O.M. (2020). Methods of designing repair and restoration bodies. Collection of scientific works of the military academy (Odessa), 2020. No 13 (1), part I, p. 210-222. DOI: 10.37129/23137509.2020.13.1.210-222

4. Dachkovskyi, V., Sampir, O., \& Horbachova, Y. (2020). Methodical approach to evaluation of economic efficiency of repairing the weapons and military equipment. VUZF Review, 5(1), 2230. DOI: $10.38188 / 2534-9228.20 .1 .03$
5. Honchar, R.O. Vlasov, KV Zabula, OE Method of conducting technical reconnaissance by units of the National Guard of Ukraine using unmanned aerial vehicles. Collection of scientific works of the Military Institute of Internal Troops of the Ministry of Internal Affairs of Ukraine. 2019. № 3 (70). p.210-222. ISSN 2078-7480

6. Volkov, O. I., Pevtsov, G. V., Klimenko, V. A., Sytnyk, Yu. B. (2010). Evaluation of the effectiveness of air reconnaissance in planning the combat use of its means. Science and Technology of the Air Force of the Armed Forces of Ukraine. 2010. № 2 (4). P. 36-40.

7. Nevgad, S. S., Kornienko A. P. (2009). Experience of conducting air reconnaissance of masked objects. Collection of scientific works of Kharkiv University of the Air Force. 2009. № 1 (19). P. 21-25. ISSN 2073-7378

8. Turcan, M., \& Dachkovsky, V. (2021). Methods for assessing the possibility of implementing measures to repair weapons and military equipment. Collection of scientific works "ヘ'ОГОГ". $\quad$ DOI: $10.36074 /$ logos19.03.2021.v1.49 
9. Kotsyuruba, V. I., Dachkovsky, B. O. (2020). Methods for evaluating the effectiveness of the system of restoration of armaments and military equipment. Modern information technologies in the field of security and defense, № 1 (37) P. 5-14. DOI: 10.33099/23117249/2020-37-1-5-14

10. Hudyma, V., Dachkovsky, V., \& Sampir, O. (2021). Methodical approach to forecasting the flow of the repair fund of samples of weapons and military equipment. Collection of scientific works "Л'ОГО之". DOI: 10.36074/logos26.02.2021.v1.40

11. Dachkovskyi, V. (2019). Methodology of justification of tactical and technical requirements for movable means of repairing arms and military equipment. Journal of Scientific Papers "Social Development and Security», 9(6), 86-101. DOI: 10.33445/sds.2019.9.6.7

12. Dachkovskyi, V. (2021). Methods of evaluation of efficiency of logistic operations. Journal of Scientific Papers "Social Development and Security", 11(1), 179-196. DOI: 10.33445/sds.2021.11.1.17

13. Pat. 102083 Ukraine, IPC (2013) F41H 7/00. Technical reconnaissance machine (TRM-1) / Dachkovsky V.O.; - applicant and patent holder Dachkovsky V.O. - № u201504517; application. 08/05/2015; publ. 10/12/2015; Bull. № 19 . Available from: https://uapatents.com/8-102083-mashinatekhnichno-rozvidki-mtr-1.html

14. Pat. 105092 Ukraine, IPC (2013) F41H 7/00. Technical reconnaissance machine (TRM-2) / Dachkovsky VO, Kotsyuruba VI, Datsenko IP; applicant and patent holder of the NGO - № u201506514; application. 02.07.2015; publ. 10.03.2016; Bull. № 5. Available from: https://uapatents.com/6-105092-mashinatekhnichno-rozvidki-mtr-2.html

15. Pat. 122446 Ukraine, IPC (2009) F41 H 7/00. Basic caterpillar platform of modular type / Dachkovsky V.O., Ovcharenko I.V., Yaroshenko
O.V., Sampir O.M., Kurovskaya T.Yu. - applicant and patent holder Dachkovsky V.O. - № a201812481; application. 12/17/2018; publ. 10.11.2020, Bull. №21 / 2020. Available from: https://base.uipv.org/searchINV/search.php?a ction=viewdetails \&IdClaim $=272217$

16. Pat. 135430 Ukraine, IPC (2017) B60 S 5/00. Technical assistance machine (TAM-B) / Dachkovsky V.O., Sampir O.M., Yaroshenko O.V., Ovcharenko I.V., - applicant and patent holder National Defense University of Ukraine named Ivan Chernyakhovsky - № u201901427; application. 12/02/2019; publ. 25/06/2019; Bull. № 12 . Available from: https://base.uipv.org/searchINV/search.php?a ction=viewdetails\&IdClaim $=259811$

17. Levchenko, M. A., Dachkovsky, V. O. Mathematical model of technical intelligence tasks. International Scientific Journal "Grail of Science" № 6 (June, 2021): based on the materials of the I International Scientific and Practical Conference "Modern Science: Concepts, Theories and Methods of Basic and Applied Research", held on June 25, 2021 "International Center for Corporate Governance" (Vienna, Austria). pp. 87-90. DOI: 10.36074/grail-of-science.25.06.2021.015

18. Levchenko, M. A., Dachkovsky, V. O. Evaluation of the effectiveness of the use of mobile means of repairing weapons and military equipment Scientific collection "InterConf" (66): with the materials of the 9th International Scientific and Practical Conference "Challenges in the Science of Modernity" (July 16-18, 2021). Washington, USA: Endeavors Publishing House, 2021 510513. DOI: 10.36074/logos-19.03.2021.v1.49

19. Ishchenko, Nikolay, Adamovska, Victoriia and Krasnova, Anna (2019), "Features assess the effectiveness of management decisions by local governments", Derzhavne upravlinnya: udoskonalennya ta rozvytok, [Online], vol. 6, DOI: 10.32702/2307-2156-2019.6.2 